\title{
ARTICLE
}

\section{PAYING FOR LONG-TERM PERFORMANCE}

\section{LUCIAN A. BEBCHUK ${ }^{\dagger} \&$ JESSE M. FRIED ${ }^{\dagger+}$}

Firms, investors, and regulators around the world are now seeking to ensure that the compensation of public company executives is tied to long-term results, in part to avoid incentives for excessive risk taking. This Article examines how best to achieve this objective. Focusing on equity-based compensation, the primary component of executive pay, we identify how such compensation should best be structured to tie pay to long-term performance. We consider the optimal design of limitations on the unwinding of equity incentives, putting forward a proposal that firms adopt both grant-based and aggregate limitations on unwinding. We also analyze how equity compensation should be designed to prevent

\footnotetext{
${ }^{\dagger}$ Friedman Professor of Law, Economics, and Finance and Director of the Program on Corporate Governance, Harvard Law School. While Lucian Bebchuk served as a consultant to the Department of the Treasury Office of the Special Master on Executive Compensation, the views expressed in this Article (which was largely written prior to the beginning of Bebchuk's consulting appointment) do not necessarily reflect the views of the Office of the Special Master or of any other individual affiliated with that Office.

it Professor of Law, Harvard Law School.

For helpful discussions and comments, we would like to thank Carr Bettis, Jesse Brilla, John Cannon, Alma Cohen, Kenneth Feinberg, Brian Foley, Robert Jackson, Jon Lukomnik, Kevin Murphy, Nitzan Shilon, Holger Spamann, and participants at a New York University symposium and the 2010 Institute for Law and Economic Policy conference on Protection of Investors in the Wake of the 2008-2009 Financial Crisis. Matt Hutchins provided valuable research assistance. For financial support, we are grateful to the Investor Responsibility Research Center Institute for Corporate Governance; the John M. Olin Center for Law, Economics, and Business; and the Harvard Law School Program on Corporate Governance.

The Article draws on chapters fourteen and sixteen of our 2004 book, Pay Without Performance: The Unfulfilled Promise of Executive Compensation, and shorter pieces written by one or both of us for The Economists' Voice, the Journal of Applied Corporate Finance, the Wall Street Journal Online, and the Harvard Business Review Online. An earlier version of this Article was circulated in September 2009 under the title Reforming Executive Compensation.
} 
the gaming of equity grants at the front end and the gaming of equity dispositions at the back end. Finally, we emphasize the need for widespread adoption of limitations on executives' use of hedging and derivative transactions that weaken the tie between executive payoffs and the long-term stock price that welldesigned equity compensation is intended to produce.

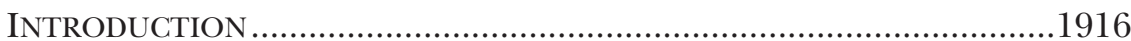

I. LIMITATIONS ON UNWINDING EQUITY INCENTIVES .....................1922

A. Separating Vesting and Freedom to Unwind ........................1923

B. The Problem with Retirement-Based Holding Requirements....1925

C. Grant-Based Limitations on Unwinding ..............................1928

D. Aggregate Limitations on Unwinding....................................1931

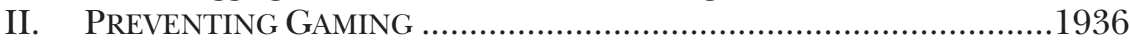

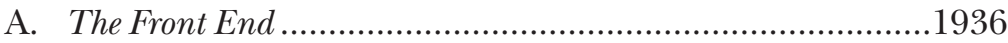

1. The Timing of Equity Grants ...............................1937

2. Stock-Price Manipulation Around

Equity Grants..........................................................1940

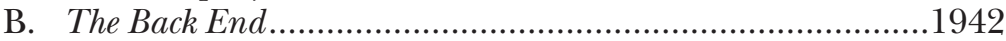

1. Gaming Problems at the Back End ......................1942

a. Using Inside Information to Time

Equity Unwinding ....................................1942

b. Stock-Price Manipulation

Around Unwinding ....

2. Addressing Gaming Problems at the Back End...1945

a. Average-Price Payoffs.................................1945

b. The Need for Additional Steps ......................1947

c. Pretrading Disclosure...................................1948

d. "Hands-Off" Arrangements ..........................1950

III. LIMITATIONS ON HEDGING AND DERIVATIVE TRANSACTIONS.......1951

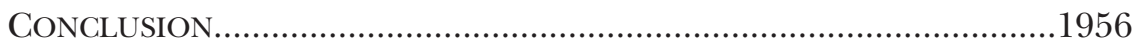

APPENDIX: PRINCIPLES FOR TYING EQUITY COMPENSATION

TO LONG-TERM PERFORMANCE

\section{INTRODUCTION}

In the aftermath of the financial crisis, regulators, firms, and investors are seeking to put in place executive pay arrangements that avoid rewarding executives for short-term gains that do not reflect long-term performance. This Article seeks to contribute to these efforts by analyzing how pay arrangements can and should best be tied to long-term performance. Our analysis focuses on equity-based compensation, the most important component of executive pay arrangements. 
In our 2004 book, Pay Without Performance: The Unfulfilled Promise of Executive Compensation, we warned that standard executive pay arrangements were leading executives to focus excessively on the short term, motivating them to boost short-term results at the expense of long-term value. ${ }^{1}$ The crisis of 2008-2009 has led to widespread recognition that pay arrangements that reward executives for short-term results can produce incentives to take excessive risks. Leading public officials, such as Federal Reserve Chairman Ben Bernanke ${ }^{2}$ and Treasury Secretary Timothy Geithner, ${ }^{3}$ as well as top business leaders such as Goldman Sachs's CEO Lloyd Blankfein, ${ }^{4}$ have all emphasized the importance of avoiding such flawed structures.

Recognition of the significance of the problem has generated substantial interest in fixing it. Treasury Secretary Geithner has urged corporate boards to "pay top executives in ways that are tightly aligned with the long-term value and soundness of the firm." ${ }^{5}$ The Troubled Asset Relief Program (TARP) bill, ${ }^{6}$ subsequent legislation amending TARP, ${ }^{7}$ and the Treasury regulations implementing $\mathrm{TARP}^{8}$ all required the eli-

\footnotetext{
${ }^{1}$ See Lucian Bebchuk \& Jesse Fried, Pay Without Performance: The UnfulFILLED PROMISE OF EXECUTIVE COMPENSATION ch. 14 (2004) (analyzing problems resulting from the broad freedom of executives to unload equity incentives); see also Richard Bernstein, Vindication for Critic of C.E.O. Pay, INT'L HERALD TriB., June 18, 2009, at 2, available at 2009 WLNR 11595028 (arguing that the analysis in our book was vindicated by the subsequent financial crisis).

${ }^{2}$ See Ben S. Bernanke, Chairman, Bd. of Governors of the Fed. Reserve Sys., Speech at the Independent Community Bankers of America's National Convention and Techworld (Mar. 20, 2009), transcript available at http://www.federalreserve.gov/ newsevents/speech/bernanke20090320a.htm (" $[\mathrm{P}]$ oorly designed compensation policies can create perverse incentives .... Management compensation policies should be aligned with the long-term prudential interests of the institution, be tied to the risks being borne by the organization, ... and avoid short-term payments for transactions with long-term horizons.").

${ }^{3}$ See Press Release, U.S. Dep't of the Treasury, Statement by Treasury Secretary Tim Geithner on Compensation (June 10, 2009), available at http://www.ustreas.gov/press/ releases/tg163.htm ("[C]ompensation should be structured to account for the time horizon of risks.").

${ }^{4}$ See Lloyd Blankfein, Do Not Destroy the Essential Catalyst of Risk, FIN. TIMES, Feb. 9, 2009, at 13 ("An individual's performance should be evaluated over time so as to avoid excessive risk-taking.”).

${ }^{5}$ Press Release, U.S. Dep't of the Treasury, supra note 3.

${ }^{6}$ See Emergency Economic Stabilization Act of $2008 \S 111(\mathrm{~b})(2), 12$ U.S.C. $\S 5221$ (b) (2) (Supp. II 2009).

7 See American Recovery and Reinvestment Act of 2009, Pub. L. No. 111-5, sec. 7001, § 111, 123 Stat. 115, 516-20 (amending section 111(b) of the Emergency Economic Stabilization Act).

${ }^{8}$ See, e.g., Press Release, U.S. Dep't of the Treasury, Treasury Announces New Restrictions on Executive Compensation (Feb. 4, 2009), available at http://www.ustreas.gov/
} 
mination of incentives to take "unnecessary and excessive risks" in firms receiving TARP funds. The Interim Final Rule on TARP Standards for Compensation and Corporate Governance, which appointed Kenneth Feinberg as the Special Master for TARP Executive Compensation, instructed Feinberg to focus on tying pay to long-term performance. ${ }^{9}$ The Treasury's plan for financial regulatory reform called on federal regulators to issue standards for all financial firms to avoid excessive risks, ${ }^{10}$ and a bill recently passed by the House of Representatives requires regulators to adopt such standards. ${ }^{11}$ In the meantime, regulators have been moving on their own in this direction: the Federal Reserve Board of Governors requested comments on a proposed guidance contemplating the scrutiny of pay arrangements by banking supervisors, ${ }^{12}$ and the Federal Deposit Insurance Corporation (FDIC) requested comments on a proposal to raise deposit insurance rates for banks whose compensation arrangements create excessive incentives to take risks. ${ }^{13}$

At the international level, the Basel II framework has been recently amended to require banking regulators to monitor compensation structures with a view to aligning them with good risk management. ${ }^{14}$ At their September 2009 meeting, the G-20 leaders "committed to act together to... implement strong international compensation stan-

press/releases/tg15.htm (describing the Treasury guidelines promulgated under the Emergency Economic Stabilization Act).

9 See TARP Standards for Compensation and Corporate Governance, 74 Fed. Reg. 28,394 (June 15, 2009) (to be codified at 31 C.F.R. pt. 30) (establishing guidelines for executive compensation at firms receiving TARP assistance).

${ }^{10}$ See U.S. DeP'T OF THE TrEasury, FinANCial Regulatory Reform: A NEW FounDATION 28 (2009), available at http://www.financialstability.gov/docs/regs/FinalReport_ web.pdf (outlining the Obama Administration's recommendations to reform and restructure the financial regulatory system); see also Press Release, U.S. Dep't of the Treasury, Treasury Secretary Tim Geithner Written Testimony House Financial Services Committee Hearing (Mar. 26, 2009), available at http://www.ustreas.gov/press/releases/ tg71.htm ("[R]egulators must issue standards for executive compensation practices across all financial firms ... [that] encourage prudent risk-taking . . . and should not otherwise create incentives that overwhelm risk management frameworks.").

${ }^{11}$ See Corporate and Financial Institution Compensation Fairness Act of 2009, H.R. 3269, 111th Cong. §4(b) (2009) (“[R] egulators shall jointly prescribe regulations that prohibit any incentive-based pay arrangement ... [that] encourages inappropriate risks.").

${ }^{12}$ Proposed Guidance on Sound Incentive Compensation Practices, 74 Fed. Reg. 55,227 (proposed Oct. 27, 2009).

${ }^{13}$ Incorporating Employee Compensation Criteria into the Risk Assessment System, 75 Fed. Reg. 2823 (proposed Jan. 19, 2010) (to be codified at 12 C.F.R. pt. 327).

${ }^{14}$ See Basel Comm. On Banking Supervision, Enhancements to the Basel II FRAMEWORK paras. 84-94 (2009) (providing guidance on measures that would enhance sound compensation practices, such as decoupling compensation from short-term profit and actively monitoring the compensation system's operation). 
dards aimed at ending practices that lead to excessive risk-taking." ${ }^{, 15}$ The U.K. Financial Services Authority has adopted regulations aimed at ending such practices, ${ }^{16}$ and other countries have been moving or considering moves in such a direction. ${ }^{17}$

While there is thus widespread recognition that improving executives' long-term incentives is desirable, there is much less agreement as to how this should be accomplished. The devil here, not surprisingly, is in the details. In this Article, building on our earlier work, we seek to contribute to pay-arrangement reform by providing a framework and a blueprint for tying executives' equity-based compensation-the primary component of their pay packages-to long-term performance.

Part I analyzes how executives should be encouraged to focus on the long term rather than the short term. The key principle should be, as we argued in Pay Without Performance, ${ }^{18}$ that managers must hold a large fraction of their equity after it vests. The analysis in Part I focuses on the optimal design of limitations on unwinding. We argue against the proposal that executives should be prevented from unwinding equity incentives until their retirement. Tying the freedom to cash out to retirement, we show, can distort executives' decisions to retire as well as undermine their incentives to focus on long-term value when approaching retirement. Instead, we put forward unwinding limitations designed to prevent executives from attaching excessive weight to shortterm prices without creating perverse incentives to retire. An executive receiving an equity-based grant should not be free to unwind the received equity incentives for a specified period of time after vesting, after which she should be permitted to unwind the equity only gradually. In addition, an executive's unwinding of shares should be subject to ag-

\footnotetext{
${ }^{15}$ See Leaders' Statement: The Pittsburgh Summit pmbl., para. 17, at 2 (2009), available at http:/ / www.pittsburghsummit.gov/documents/organization/129853.pdf.

${ }^{16}$ See FIN. SERvS. AUTH., REFORMING REMUNERATION PRACTICES IN FINANCIAL SERVICES app. 1 (2009), available at http://www.fsa.gov.uk/pubs/policy/ps09_15.pdf (discussing a new framework to regulate the compensation practices of the financial services industry, including requirements to establish remuneration policies consistent with and promoting effective risk management, along with increasing supervisory focus on remuneration)

17 See, e.g., Swiss Fin. MKt. Supervisory Auth. (FINMA), REMUneration SysTEMS: Minimum STANDARDS FOR REMUNERATION SYSTEMS OF FINANCIAL INSTITUTIONS paras. 23, 27, 30 (2010), available at http:/ /www.finma.ch/e/regulierung/Documents/ finma-rs-2010-01-e.pdf (requiring transparent, long-term-based remuneration schemes, independent control over the implementation of these schemes, and the structuring of remuneration to enhance risk awareness).

${ }^{18}$ BEBCHUK \& FRIED, supra note 1, at 174-79.
} 
gregate limits on the fraction of the executive's portfolio of equity incentives that the executive may unwind in any given year.

Part II describes how executive compensation arrangements should be structured to prevent various types of "gaming" that work to increase executive pay at public shareholders' expense and, in some cases, worsen executives' incentives: so-called "springloading" (using inside information to time equity grants); selling on inside information; and the manipulation of the stock price around equity grants and dispositions. We discuss how to control both gaming at the "front end"-when equity is granted—and gaming at the "back end"—when equity is cashed out.

At the front end, the timing of equity grants should not be discretionary, and equity awards should be made only on certain prespecified dates. In addition, the terms and value of equity grants should not be linked to the grant-date stock price, which can easily be manipulated. The combination of these two steps at the front end would substantially reduce both springloading and stock-price manipulation around equity grants. At the back end, we propose arrangements that would reduce executives' ability and incentive to time dispositions based on inside information, as well as reduce executives' ability and incentive to manipulate the stock price around the time of disposition. Executives could be required to announce their intentions to unwind equity in advance. Firms could also use "hands-off" arrangements under which an executive's vested equity incentives are automatically cashed out according to a schedule specified when the equity incentives are initially granted.

Finally, Part III advocates that firms adopt arrangements designed to ensure that executives cannot easily evade the proposed arrangements-both those that require executives to hold equity for the long term and those that prevent gaming. Deploying arrangements that are desirable in theory will have little effect if they can be easily circumvented in practice. We therefore explain the importance of placing robust restrictions on the use of any hedging or derivative transaction that would enable executives to profit, or would protect them, from declines in their company's stock price.

During the course of our analysis in Parts I through III, we distill our conclusions into eight "principles." In an Appendix, we assemble them into a list of eight principles for tying equity-based compensation to long-term performance.

Before proceeding, we would like to comment on the scope of our analysis and note several issues that fall outside of it. To begin, our analysis focuses on equity-based compensation and does not extend to 
bonus compensation, which also needs to be reformed to prevent executives from attaching excessive weight to short-term results. As for equity-based compensation, we do not analyze the elements of longterm shareholder value for which executives should and should not be rewarded. Thus, we do not consider here whether executives should be paid with restricted stock or options, or the extent to which the payoffs from these equity instruments should be designed to filter out changes in the stock price that are due to market-wide or industrywide fluctuations. Our focus is on ensuring that, whatever equity incentives are used, their payoffs are primarily based on long-term stock values rather than on short-term gains that may be reversed.

We should also emphasize that our analysis focuses on the compensation arrangements of firms' top executives. For lower-level executives with responsibility over units whose performance does not have a substantial effect on the firm's stock price, bonus compensation (whether provided in cash or in stock) provides the most effective way to tie compensation to long-term results. For top executives, however, equity-based compensation provides an effective way to link pay to performance, and such compensation is in fact a primary component of their pay packages. Reforming the pay arrangements of these top executives in the ways proposed by this Article would thus substantially improve their incentives to focus on the firm's long-term performance. Furthermore, to the extent that a firm's top executives have substantial influence on the pay structures of lower-level executives, improving top executives' pay arrangements in the ways we discuss below will indirectly contribute to improving lower-level executives' pay structures as well. In particular, when top executives' compensation is tied to long-term shareholder value, these executives will have a powerful incentive to adopt arrangements that similarly tie lower-level executives' pay to long-term shareholder value. ${ }^{19}$

${ }^{19}$ We assume, for purposes of this Article, that the long-term stock price reflects the cash flow to shareholders over time and that it is thus appropriate to tie executive pay to the long-term stock price. However, to the extent the firm engages in share repurchases or equity issuances, the long-term stock price will not accurately reflect the cash flow to shareholders over time. For an analysis of this problem and how the proposals of this Article need to be adjusted to address it, see generally Jesse M. Fried, Share Repurchases, Equity Issuances, and the Optimal Design of Executive Pay (Feb. 2010) (unpublished manuscript, on file with author). 


\section{LIMITATIONS ON UNWINDING EQUITY INCENTIVES}

The problem we identified in Pay Without Performance is that many standard features of pay arrangements have failed to provide managers with desirable incentives to generate value..$^{20}$ Indeed, they have often produced perverse incentives to act in suboptimal, value-reducing ways. One important example: pay arrangements have rewarded executives for short-term results that do not necessarily reflect long-term performance and that may in fact be generated at the expense of long-term value.

Consider an executive who expects to be rewarded at the end of a given year based on performance measures tied to the stock price at the end of that year. This compensation structure may lead to two types of undesirable behavior. First, managers may take actions that boost the stock price in the short run, even if such actions would destroy value in the long run. For example, executives may enter into transactions that improve the current bottom line but create large latent risks that could cripple the firm in the future. Second, managers may engage in financial manipulation or other forms of "window dressing" that do not build firm value merely to pump up short-term prices. In both cases, executives receive higher pay even though they fail to build firm value. And in the first scenario, executives receive more pay even though they destroy firm value. Thus, rewarding executives for short-term results not only fails to serve the goal of encouraging executives to improve firm performance-it can actually work in the opposite direction.

Equity compensation arrangements should, therefore, provide exexecutives with incentives to maximize long-term value, not the shortterm stock price. But how should this be achieved? Section I.A begins by emphasizing the value of imposing limits on the unwinding of vested equity incentives - that is, of separating the time at which executives become free to unwind equity incentives from the time at which such incentives vest. Section I.B explains that requiring executives to hold their equity until retirement, as some have proposed, would create undesirable incentives. Sections I.C and I.D put forward a better approach. In particular, we discuss the value and optimal design of grant-based limitations on unwinding in Section I.C and aggregate limitations on unwinding in Section I.D.

\footnotetext{
${ }^{20}$ See BEBCHUK \& FRIED, supra note 1 , at 174-85 (identifying various incentive problems that current pay arrangements produce).
} 


\section{A. Separating Vesting and Freedom to Unwind}

Executive compensation arrangements usually include stock options, restricted stock, or a combination of the two. Under a typical stock option plan, a specified number of options vests each year as compensation for that year's work. Such a vesting schedule encourages an executive to remain with the firm. Once options vest-i.e., once they are "earned"- the options typically remain exercisable for ten years from the grant date. However, standard arrangements allow executives to exercise the options and sell the underlying shares immediately upon the vesting of their options.

Restricted stock grants operate in much the same manner as stock option plans. The stock is called "restricted" because executives do not own the stock outright when it is granted. Rather, ownership of the stock vests over time, in part to give the executive an incentive to stay on the job. When the vesting period ends, the restricted shares "belong" to the executive and, as in the case of options, executives are generally free to cash them out.

Not surprisingly, executives take full advantage of their freedom to unload equity incentives after vesting. For example, executives commonly exercise stock options years before they expire, and they immediately sell almost all of the shares they acquire through option exercises. ${ }^{21}$ As a result, executives are frequent sellers of their firms' stock. ${ }^{22}$

As we explained in Pay Without Performance, such early unwinding imposes two types of costs on shareholders. ${ }^{23}$ First, the corporation must give the unwinding executive fresh equity grants to replenish her holdings; otherwise, the executive's incentive to generate shareholder value will be diminished. ${ }^{24}$ These replenishment grants economically dilute current public shareholders' holdings by reducing their fractional ownership of the corporate pie. If executives were unable to unwind their stock and options so quickly after vesting, the cost of replenishing executives' equity positions would be lower.

Second, and more importantly for our focus in this Article, the ability to sell equity shortly after vesting leads executives to focus excessively

\footnotetext{
${ }^{21}$ See id. at 176-77 (noting studies that demonstrate executives' widespread freedom to unwind early and executives' tendency to exercise their options and sell the underlying shares well before the options' expiration).

${ }^{22}$ Cf. Jesse M. Fried, Reducing the Profitability of Corporate Insider Trading Through Pretrading Disclosure, 71 S. CAL. L. REV. 303, 317-27 (1998) (surveying evidence of insider trading by corporate executives).

${ }^{23}$ BEBCHUK \& FRIED, supra note 1 , at 175.

${ }^{24} I d$.
} 
on short-term prices-the prices at which they can unload their shares and options. ${ }^{25}$ At any given point in time, executives may have accumulated-and wish to unload-a large number of vested shares or options. Once executives have decided to sell large amounts of stock, they might find it in their interest to increase the short-term stock price, even if doing so would reduce the corporation's long-term value. ${ }^{26}$

Both of the costs associated with unwinding can be mitigated by the approach we advocated in Pay Without Performance: separating the time that most of the restricted stock or options can be cashed out from the time that the equity vests. ${ }^{27}$ By requiring an executive to hold the equity for a longer period of time, the board will not need to replenish that executive's holdings as frequently. This, in turn, will reduce the cost to shareholders of maintaining the executive's equity ownership at an adequate level. More importantly for the purposes of this Article, this requirement will reduce the executive's incentive to focus on the short term since the payoff from her equity will depend on stock prices in the long run.

Although the end of the vesting period and the earliest cash-out date are almost always the same under current option and restricted stock plans, there is no reason for the two dates to be identical. As soon as an executive has completed an additional year at the firm, the restricted stock or options that were promised as compensation for that year's work should vest: they should belong to the executive even if the executive immediately leaves the firm. But the fact that the equity is now the executive's to keep does not mean that the executive should be able to cash out all the equity immediately.

Under current tax rules, an executive may be liable for taxes upon the vesting of certain equity incentives. ${ }^{28}$ In such circumstances, it may well be desirable to permit the executive to cash out enough of the vested equity incentives to pay the taxes arising from vesting. Cashing out vested equity incentives solely to pay taxes would not result in the executive's pocketing any cash; the executive's ultimate payoff would continue to depend on the stock's value down the road.

\footnotetext{
${ }^{25}$ See id. at $175-76$.

${ }^{26}$ See id.

${ }^{27}$ See id. at 175 .

${ }^{28}$ For example, the vesting of restricted stock generally gives rise to a tax liability. See I.R.C. § 83(a) (2006) (triggering tax liability when "the rights of the person having the beneficial interest in such property are transferable or are not subject to a substantial risk of forfeiture").
} 
This leads us to:

PRINCIPLE 1: Executives should not be free to unload restricted stock and options as soon as they vest, except to the extent necessary to cover any taxes arising from vesting.

As we will explain in Part II, allowing executives to time their sales gives executives incentives to engage in two types of gaming: trading on inside information and manipulating the stock price before a large sale. Thus, if a tax liability arises from the vesting of equity awards, the executive should not be given discretion over when she sells the equity necessary to cover that liability. Instead, the firm should withhold enough shares (based on the vesting-date price) to cover the executive's taxes. Alternatively, the executive could be permitted to sell that amount of equity back to the firm at the vesting-date price. In either case, the executive would have little incentive or ability to engage in the gaming that can occur when executives are permitted to choose the precise time at which they unwind their equity.

\section{B. The Problem with Retirement-Based Holding Requirements}

If, as we propose, cash-out dates are separated from vesting dates, the length of the "blocking" period between vesting and cash-out must be determined. Some commentators and shareholder activists have proposed that firms link the cash-out date to retirement. ${ }^{29}$ Such an

${ }^{29}$ See "Hold Through Retirement": Maximizing the Benefits of Equity Awards While Minimizing Inappropriate Risk Taking, CORP. EXECUTIVE, Nov.-Dec. 2008, at 1, 3 [hereinafter "Hold Through Retirement"] (listing the benefits of retirement-based policies); Sanjai Bhagat \& Roberta Romano, Reforming Executive Compensation: Focusing and Committing to the Long-Term 1 (Yale Law Sch. John M. Olin Ctr. for Studies in Law, Econ., \& Pub. Policy, Research Paper No. 374, 2009), available at http://ssrn.com/abstract=1336978 ("[E]xecutive incentive compensation plans should consist only of restricted stock and restricted stock options, restricted in the sense that the shares cannot be sold or the option cannot be exercised for a period of at least two to four years after the executive's resignation or last day in office." (emphasis omitted)); Press Release, AFSCME, AFSCME Employees Pension Plan Announces 2009 Shareholder Proposals (Jan. 27, 2009), available at http://www.afscme.org/press/24815.cfm (reporting AFSCME's shareholder proxy proposals calling for "hold through retirement" compensation schemes requiring executives "to retain a significant percentage of shares acquired through equity compensation programs for two years past their termination of employment with a company"); see also Alex Edmans, Xavier Gabaix, Tomasz Sadzik \& Yuliy Sannikov, Dynamic Incentive Accounts (Ctr. for Econ. Policy Research, Discussion Paper No. 7497, 2009), available at http://www.cepr.org/pubs/dps/DP7497.asp (proposing "incentive accounts" with state-dependent balancing and time-dependent vesting that continues for a specified period after retirement). 
approach would block executives from unwinding awarded equity incentives until after they retire from their firms.

Several dozen firms, including Exxon Mobil, Citigroup, and Deere, have adopted hold-till-retirement plans that require executives to hold stock until they step down. ${ }^{30}$ As soon as the executives retire, they are free to unload the stock. For example, Citigroup requires that directors and the Executive Committee of its senior management hold seventyfive percent of the net shares granted to them under the firm's equity programs until they leave those positions. This holding requirement resets at age sixty-five if the covered person has not yet retired. ${ }^{31}$

The appeal of retirement-based cash-out dates is understandable. Such an approach would reduce the costs of replenishing executives' equity holdings. It would also cause executives to focus more on the long term - the anticipated value of their equity as of retirement-and less on the short term.

Unfortunately, permitting executives to sell their shares upon retirement may also create perverse incentives. In particular, a hold-tillretirement requirement may cause an executive to elect to retire even though the firm could still benefit from her services. Suppose, for example, that an executive with large amounts of unliquidated equity has information suggesting that the firm's stock is overvalued and that, for reasons unrelated to the executive's future performance, the stock price is likely to decline over the next several years. Resigning at once would enable the executive to unload the accumulated equity earlier, and the prospect of large profits from such an unwinding may induce the executive to leave. If the executive is the best person to run the firm, her departure could impose a substantial cost on the firm and its shareholders. Retirement-based cash-out dates may, therefore, undermine the important retention purpose of equity arrangements. Rather

\footnotetext{
${ }^{30}$ See Exxon Mobil Corp., Definitive Proxy Statement (Schedule 14A), at 25 (Apr. 13,2009 ) ("50 percent of each grant is restricted for five years; and, [t] he balance is restricted for 10 years or until retirement, whichever is later." (emphasis omitted)); Citigroup Inc., Definitive Proxy Statement (Schedule 14A), at 29 (Mar. 20, 2009) ("As part of our commitment to aligning employee and stockholder interests, members of the management executive committee and members of the board of directors have agreed to hold $75 \%$ of the shares of common stock they acquire through Citigroup's equity programs as long as they remain subject to the stock ownership commitment."); Deere \& Co., Definitive Proxy Statement (Schedule 14A), at 61 (Jan. 13, 2010) ("RSUs granted in fiscal 2009 and 2008 must be held until retirement or other permitted termination of employment....").

${ }^{31}$ Citigroup Inc., Definitive Proxy Statement, supra note 30, at 29.
} 
than provide retention benefits, equity-based compensation with a holdtill-retirement requirement might push the executive out.

Even more perversely, retirement-based blocking provisions could lead the most successful executives to retire. The executives with the strongest temptation to quit will be those with the largest amounts of unliquidated equity. The value of such equity will generally be higher when the executive has generated considerable returns for shareholders over a long period of time. Tying equity unwinding to retirement may therefore provide an especially strong incentive for long-serving and successful executives to leave their firms. ${ }^{32}$

In addition, if the executive is permitted to cash out all of her blocked equity immediately upon retirement, the arrangement will encourage her to place excessive weight on short-term results in her last year or two of service. Consider an executive who plans to leave within the next two years, either because of the retirement-based cashout provision or for some other reason. Knowing that she will be able to cash out all of her equity in one or two years, the executive will have an incentive to pay too much attention to the stock price around the time of her retirement.

Some who urge companies to adopt retirement-based holding plans have suggested that executives be required to hold their shares for one or two years following retirement. ${ }^{33}$ Such a postretirement holding requirement would reduce, but not eliminate, the costs of hold-till-retirement plans discussed above. Under such an arrangement, retirement would not enable immediate unwinding. However, it could still substantially accelerate executives' ability to unwind some of their vested equity incentives. As a result, retirement-based plans with a postretirement holding requirement of one or two years could still produce perverse incentives to retire prematurely. Furthermore, while requiring an executive to hold equity incentives for one or two

${ }^{32}$ More generally, one must be careful of arrangements that enable an executive to cash out her equity on the occurrence of some event $X$, where $X$ is at least partly under the control of the executive and may not always be desirable. For example, the federal government limits the ability of executives of TARP firms to cash out their restricted stock until the government is repaid in full. See TARP Standards for Compensation and Corporate Governance, 74 Fed. Reg. 28,394, 28,410 (June 15, 2009) (restricting transferability until, among other conditions, " $[\mathrm{t}]$ he remainder of the shares or units granted at the time of repayment of $100 \%$ of the aggregate financial assistance received"). Although this restriction is understandable-it reduces executives' ability to reap large stock profits before taxpayers recover their investment-it may give the executives a strong personal incentive to repay the government even if this would leave their firms with insufficient capital.

33 See, e.g., Press Release, AFSCME, supra note 29. 
years after retirement would prevent an executive about to retire from focusing exclusively on stock prices in the very short term, the executive's horizon could still be limited to one or two years, with insufficient weight placed on stock values in the longer term.

Given these two drawbacks of existing and proposed retirementbased holding requirements-incentivizing early retirement and encouraging a focus on short-term performance immediately before retirement-it is important to employ holding requirements that do not encourage executives to retire early or place a large weight on the short term as the executives approach retirement. We will later discuss alternative limitations on unwinding that would not produce such perverse incentives. Before proceeding, however, we can state the lesson of this Section's discussion:

PRINCIPLE 2: Executives' ability to unwind their equity incentives should not be tied to retirement.

\section{Grant-Based Limitations on Unwinding}

We begin by discussing grant-based limitations that should be placed on the unwinding of equity incentives. By "grant-based limitations," we mean restrictions that are defined with respect to each equity grant awarded to an executive. The grant-based limitation we favor, based on a proposal in Pay Without Performance, would allow an executive to unload increasing amounts of equity as time passes from the vesting date of a particular equity grant. ${ }^{34}$

For example, after allowing for whatever cashing out of vested equity incentives is necessary to pay any vesting-related taxes, an executive might be required to hold all remaining equity incentives for two years after vesting. On the two-year anniversary of vesting, the executive would be free to unwind twenty percent of the grant. On each of the following anniversary dates, the executive would be free to unwind another twenty percent of the grant. So the executive would be permitted to sell the first twenty percent two years after vesting, forty percent three years after vesting, and the entire amount six years after vesting. We call this the "fixed-date" approach because stock becomes freely transferable on fixed dates, rather than upon retirement or some other date chosen or influenced by the executive.

\footnotetext{
${ }^{34}$ See BEBCHUK \& FRIED, supra note 1, at 174-76 (describing the benefits of a restricted-unwinding arrangement).
} 
This fixed-date approach would avoid both costs associated with using a retirement-based approach. Because an executive's ability to cash out a particular equity grant is based on fixed dates on the calendar, her decision whether to remain at the firm or to retire would not be affected by the prospect of being able to unwind large amounts of equity. Whether she remains at the firm or retires, the executive can cash out that particular grant of equity when-and only when-she reaches those fixed dates.

In addition, under the fixed-date approach, executives would not have an incentive to focus on the short term as retirement approached. Because each equity grant is made at a different point of time and must be unwound gradually, the executive does not face a situation in which she can cash out almost all of her unliquidated equity at once. Thus, even when the executive is in her last year or two in office, she will still have an incentive to consider the effect of her decisions on long-term share value.

Some firms have begun adopting variants of the fixed-date approach. GE requires executives exercising options to hold any net shares that they receive for one year. ${ }^{35}$ Procter \& Gamble requires the CEO to hold net shares received upon the exercise of options for two years. ${ }^{36}$ Honeywell has a one-year holding policy that applies after the vesting of any stock award, including options. ${ }^{37}$ Goldman Sachs recently announced that it will pay $100 \%$ of discretionary compensation (the dominant portion of their executives' pay) in "Shares at Risk" that cannot be sold for five years. ${ }^{38}$ Similarly, Special Master for TARP Executive Compensation Kenneth Feinberg has required firms under his jurisdiction to pay some of their executives in stock that cannot be unloaded for at least two years. ${ }^{39}$

${ }^{35}$ Gen. Elec. Co., Definitive Proxy Statement (Schedule 14A), at 19 (Mar. 3, 2008).

${ }^{36}$ Procter \& Gamble Co., Definitive Proxy Statement (Schedule 14A), at 21 (Aug. 28, 2009).

${ }^{37}$ Honeywell Int'l Inc., Definitive Proxy Statement (Schedule 14A), at 19 (Mar. 11, 2010).

${ }^{38}$ Press Release, Goldman Sachs, Goldman Sachs Announces Changes to 2009 Compensation Program (Dec. 10, 2009), available at http://www2.goldmansachs.com/ our-firm/press/press-releases/archived/2009/compensation.html.

${ }^{39}$ See, e.g., Letter from Kenneth R. Feinberg, Office of the Special Master for TARP Executive Compensation, U.S. Dep't of Treasury, to Robert Benmosche, President and Chief Executive Officer, AIG, Inc. (Oct. 22, 2009), available at http://www.treas.gov/ press/releases/docs/20091022\%20AIG\%20Letter.pdf (requiring the majority of an individual's base salary to be paid in stock of AIG insurance subsidiaries that must be held for two years). 
One limitation of some of the arrangements noted in the preceding paragraph is that the required holding periods after vesting tend to be short. Another limitation is that, unlike our approach that provides for gradual unwinding, they make stock disposable all at once. This could lead to situations in which executives who anticipate the ability to sell a large amount of equity incentives become too focused on short-term stock prices.

One firm, Exxon Mobil, has put in place a hybrid approach that uses both fixed dates and retirement in its holding requirements. Under Exxon Mobil's plan, an executive must hold fifty percent of her stock grant until the later of ten years from grant or retirement. ${ }^{40}$ Thus, if retirement occurs early, the executive can cash out the stock only after ten years have passed since the grant date. However, if the executive continues to work at the firm for more than ten years from the grant date, she is permitted to cash out the equity only upon retirement.

Because Exxon Mobil's arrangement functions like a fixed-date plan under some circumstances, it will create better incentives than a pure retirement-based plan would in such cases. Consider Executive $A$, who received a grant five years ago and who is planning to retire well before the ten year anniversary of the grant. The plan structure would not provide Executive $A$ with any incentive to accelerate her retirement, as acceleration would not enable her to cash out the equity from the grant any earlier.

Under some circumstances, however, Exxon Mobil's plan functions like a retirement-based plan, and, in such cases, it will create undesirable incentives. Consider the situation in which ten years have passed since the equity grant to Executive $B$. Executive $B$ is considering whether to retire. Exxon Mobil's plan, which will allow her to cash out the entire equity grant upon retirement, may induce her to retire too early. In addition, whenever Executive $B$ decides to retire, the ability to cash out all of the equity from the grant at that time will induce her to pay undue attention to short-term stock prices in the period leading up to her retirement.

What of the concern that fixed-date limitations on unwinding would require an executive to hold stock after retirement and thereby subject that executive to undue risk? For example, consider a CEO receiving equity with a cash-out date in five years who is planning to retire in one year. Her final payoff will, in part, be a function of her successor's decisions in years two through five. The compensation

\footnotetext{
${ }^{40}$ Exxon Mobil Corp., Definitive Proxy Statement, supra note 30, at 25.
} 
provided to such a CEO, it might be argued, should not depend on how her successor performs.

However, the fact that the payoffs of the CEO under the fixeddate limitation could depend (for better or worse) on her successor's performance should not be too troubling. Much of a firm's stockprice movement is commonly driven by market and industry factors, rather than by firm-specific factors. Furthermore, the part of the stock performance that is due to firm-specific effects is substantially influenced by factors other than the CEO's own performance, such as the contributions of other current employees and former employees, including the former CEO. Thus, any equity-based pay arrangement subjects the CEO's payoff to a considerable amount of "noise" from factors other than her own performance. Fixed-date limitations on unwinding would be no different.

The key question is whether an executive's incentives are improved by requiring her to hold an equity grant for a fixed period of time, even if that fixed period may extend into her retirement. The answer to this question is yes. Requiring the retiring executive to hold her shares until the specified fixed date would both (1) remove any incentive for the CEO to accelerate her retirement and (2) make it less likely that she will focus on short-term results while making decisions for the firm just prior to retirement. We can thus conclude by stating the following principle:

PRINCIPLE 3: After allowing for any cashing out necessary to pay any taxes arising from vesting, equity-based awards should be subject to grant-based limitations on unwinding that allow them to be unwound only gradually, beginning some time after vesting.

\section{Aggregate Limitations on Unwinding}

The grant-based limitations we have proposed, while beneficial, do not fully address the concern that executives may place excessive weight on short-term prices. Executives serving for an extended period of time may receive a number of different equity-based grants. At any given point, the incentives of such executives-and the weight they place on short-term stock prices-will be shaped by their overall portfolio of firm stock. The incentives will depend, in particular, on the total number of equity-based instruments they will have accumulated and on the fraction of such instruments that they can freely unload in the near future. 
Consider an executive hired in 2010 who receives, in 2010 and each following year, a grant of one million shares that (other than to cover any taxes upon vesting) she cannot cash out at a rate of more than twenty percent per year, beginning two years after the end of a two-year vesting period. For the first two years after vesting, the executive will not be able to sell any shares (beyond those sold to pay any taxes), and the executive's equity awards will provide no incentive to focus on shortterm prices. During the third year of service after vesting, the executive will be free to sell twenty percent of the 2010 award but will be holding a much larger number of shares that she is not free to unload.

Suppose that this executive will serve the company for many years. Fast forward to (say) her fifteenth year. By this point, the executive may have accumulated a large number of firm shares through annual grants, a substantial fraction of which, under the grant-based restrictions, she is free to unload immediately if she so chooses. In such a case, the ability to unload a large fraction of her portfolio quickly may lead the executive to pay excessive attention to short-term prices. Grant-based limitations are thus not sufficient to avoid "short-termism" and other problems associated with executives' ability to unwind large amounts of stock at once when executives serve a significant period of time and accumulate large numbers of disposable shares.

This was the case, for example, with the top five executives at Bear Stearns and Lehman Brothers during the years preceding the firms' meltdowns. Most members of the firms' top management teams were long-serving executives who had accumulated large portfolios of shares and options. As a result, even though the firms had substantial grantbased limitations on unloading, the executives were free during this period to sell large numbers of shares relative to their total holdings. Indeed, a recent case study, which one of us coauthored with Alma Cohen and Holger Spamann, estimates that between 2000 and 2008 the top five executive teams at Bear and Lehman cashed out nearly $\$ 2$ billion of their equity: about $\$ 1.1$ billion at Bear and $\$ 850$ million at Lehman. The sales during this period enabled the executives to unwind more shares than they held when the firms failed in $2008 .^{41}$

\footnotetext{
${ }^{41}$ See Lucian A. Bebchuk, Alma Cohen \& Holger Spamann, The Wages of Failure: Executive Compensation at Bear Stearns and Lehman 2000-2008, 27 YALE J. ON REG. (forthcoming Summer 2010), available at http://ssrn.com/abstract=1513522 (reporting that Bear and Lehman executives cashed out large amounts of bonus compensation and pocketed large amounts from selling shares in the period leading up to the financial crisis of 2008-2009).
} 
To address such situations, we believe that it is important to supplement firms' grant-based limitations on unwinding with aggregate limitations on unwinding tied to the entire portfolio of vested equity that the executive has accumulated over time through her compensation arrangements. We propose that, in any given year, executives should not be permitted to unload more than a specified percentage of the total vested equity they hold at the beginning of the year. By definition and by construction, such an approach will limit the weight the executive accords to short-term results and stock prices.

For example, a firm could prohibit executives from selling, in each year, more than ten percent of the vested equity they hold at the beginning of the year. An executive subject to such an arrangement would have little incentive to increase the stock price in the coming year at the expense of the stock price in the more distant future. Even if the executive unwinds the ten percent of the shares she is free to unwind during this year, taking such steps would reduce the value of the ninety percent of the vested equity she cannot sell.

Importantly, these proposed aggregate limitations on unwinding should not end immediately upon retirement. If they did, executives might be able to unload a large amount of stock as soon as they step down. Consider, for example, a long-serving executive who has been able to accumulate a substantial amount of equity incentives. If the proposed aggregate limitation on unwinding terminates upon retirement, that executive would be free to unwind a considerable amount of stock the day after she retires. As we explained earlier, an ability to unload large amounts of stock upon retirement could have two undesirable consequences. First, it may induce an executive to retire earlier than is desirable. Second, it may lead the executive to focus too much on the short term as she approaches retirement. Therefore, terminating aggregate limitations on unwinding upon retirement could impose large costs.

Although the aggregate limitations on unwinding should not be suspended immediately upon retirement, they need not continue indefinitely after the executive retires. An aggregate unwinding limitation could instead expire several years after retirement. If executives knew they could not unwind most of their shares for (say) five years after retirement, their incentives to focus on the long term would not be undermined as they approached retirement. In addition, because retirement would not alter for several years the fraction of shares that could be sold, the additional incentive to retire would be limited. 
The principle that we thus recommend is as follows:

PRINCIPLE 4: All equity-based awards should be subject to aggregate limitations on unwinding so that, in each year (including a specified number of years after retirement), an executive may unwind no more than a specified percentage of her equity incentives that is not subject to grant-based limitations on unwinding at the beginning of the year.

Currently, many firms have "target ownership plans" that either encourage or require managers to hold a certain amount of sharesusually expressed as a multiple of the executive's salary. ${ }^{42}$ But the targets have tended to be low. In an examination of 195 firms that adopted such plans, John Core and David Larcker found that only 138 disclosed the ownership target for CEOs. ${ }^{43}$ Among these 138, the minimum level of ownership for the median CEO was four times her base salary. ${ }^{44}$ However, other elements of the compensation package, such as equity compensation and bonuses, commonly dwarf an executive's base salary. As a result, the target ownership amount may be less than one year's compensation. Furthermore, fewer than thirty percent of the firms imposed a penalty for not meeting the target. ${ }^{45}$ In many cases, the targets were purely voluntary.

Firms continue to use multiples of base salary in creating holding requirements, and these multiples are often low relative to the total compensation executives receive over time. For example, Procter \& Gamble required former CEO A.G. Lafley to hold shares or restricted stock units valued at eight times his base salary. ${ }^{46}$ This requirement may appear stringent at first glance, but Lafley would need to hold only $\$ 14$ million worth of stock-less than twenty percent of his $\$ 75$ million aggregate compensation between 2006 and 2008. ${ }^{47}$ Verizon requires CEO Ivan Seidenberg to hold shares valued at five times his base salary of $\$ 2.1$ million. $^{48}$ This $\$ 10$ million holding requirement, howev-

\footnotetext{
${ }^{42}$ John E. Core \& David F. Larcker, Performance Consequences of Mandatory Increases in Executive Stock Ownership, 64 J. FIN. ECON. 317, 326 (2002).

${ }^{43}$ See id. at 324 (compiling executive stockholding requirements).

${ }^{44} I d$.

${ }^{45}$ See id. at 320 ("52 (27\%) of our sample firms state an explicit penalty for executives who do not meet the ownership target.").

${ }^{46}$ Procter \& Gamble Co., Definitive Proxy Statement, supra note 36, at 21.

47 See id. at 37 (reporting Lafley's compensation of $\$ 23,605,453$ for 2008-2009, $\$ 23,532,410$ for $2007-2008$, and $\$ 27,735,734$ for 2006-2007).

${ }^{48}$ Verizon Commc'ns, Inc., Definitive Proxy Statement (Schedule 14A), at 39-40 (Mar. 23, 2009).
} 
er, is less than fifteen percent of the $\$ 66$ million in compensation Seidenberg received between 2006 and 2008. ${ }^{49}$ CVS Caremark also requires its CEO, Thomas Ryan, to hold five times his base salary in stock. ${ }^{50}$ Ryan's base salary is $\$ 1.4$ million, producing a share ownership target of $\$ 7$ million. That share ownership target, however, is less than ten percent of the $\$ 74$ million Ryan made between 2006 and 2008 . $^{51}$

However, some firms do appear to have more demanding requirements. A number of investment banks now require executives to hold over half of their equity awards after certain deductions. Citigroup, Goldman Sachs, JPMorgan Chase, and Morgan Stanley all require certain top executives to hold at least seventy-five percent of the shares they receive from their firms, less an allowance for the payment of the option exercise price and taxes. ${ }^{52}$ This requirement is likely to be more meaningful than standard target-ownership requirements because it is related to total equity compensation over time rather than to base salary.

In contrast to these firms' policies, which allow executives to sell a specified fraction of their total equity compensation and then leave executives with discretion as to when to make the permitted sales, our approach specifies the fraction of vested equity that executives may sell during any given year. The advantage of this approach is that it ensures that currently serving executives never unload a large block of their equity at any given time. Interestingly, at least one savvy investor found inadequate Goldman Sachs's equity holding requirements, which permit executives to sell twenty-five percent of their total accumulated equity compensation. When Warren Buffett invested in Goldman Sachs, he required its CEO and other high-ranking executives to commit to hold ninety percent of their stock for three years or until Buffett terminated his investment in Goldman Sachs (whichever comes first). ${ }^{53}$

${ }^{49}$ See id. at 40 (reporting Seidenberg's compensation of $\$ 18,573,638$ for 2008 , $\$ 26,553,576$ for 2007 , and $\$ 21,260,754$ for 2006$)$.

${ }^{50}$ CVS Caremark Corp., Definitive Proxy Statement (Schedule 14A), at 29, 33 (Mar. 24, 2009).

51 See id. at 33 (reporting Ryan's compensation of $\$ 24,102,648$ in 2008, $\$ 26,097,790$ in 2007 , and $\$ 24,020,009$ in 2006).

${ }^{52}$ Citigroup Inc., Definitive Proxy Statement, supra note 30, at 16; Goldman Sachs Group, Inc., Definitive Proxy Statement (Schedule 14A), at 16 (Apr. 6, 2009); JPMorgan Chase \& Co., Definitive Proxy Statement (Schedule 14A), at 19 (Mar. 31, 2009); Morgan Stanley, Definitive Proxy Statement (Schedule 14A), at 11 (Mar. 31, 2009).

${ }^{53}$ See Christine Harper, Goldman Executives Restrained from Stock Sales in Buffett Deal, BlOOMBERG, Oct. 3, 2008, available at http://www.bloomberg.com/apps/news?pid= 20601087\&sid=a1I3DK.6XgxY ("Goldman Sachs Group Inc.'s top four executives agreed to hold on to 90 percent of the stock they own in the company as part of Gold- 
Before concluding this Part, it is worth relating the limitations on unwinding proposed in this Part to the analysis that follows in Parts II and III. First, while the above limitations would determine how many equity instruments an executive can unload in a given year, the executive should not be free to choose the timing of those sales within the year. Rather, it would be desirable to impose restrictions on how such shares are sold, a topic we take up in Part II. Second, the proposed limitations on unwinding can be relied on to produce their intended benefits only if executives cannot circumvent them using hedging or derivative transactions. We will discuss necessary limitations on such transactions in Part III.

\section{Preventing Gaming}

Executive compensation arrangements should be structured to minimize the likelihood that executives will engage in various types of "gaming"-springloading, selling on private information, and manipulating the stock price-both prior to receiving equity grants and before unwinding that equity. We explain below what steps firms should take to reduce such gaming both at the "front end"-when equity is granted—and at the "back end"—when it is cashed out.

\section{A. The Front End}

Much attention has been focused on the problem of firms backdating option grants to executives and other employees. Over one

man's agreement to raise money from Warren Buffett's Berkshire Hathaway Inc.”). Goldman Sachs's definitive proxy statement described the agreement as follows:

Messrs. Blankfein, Cohn, Winkelried and Viniair each have agreed that, with certain exceptions, until the earlier of October 1, 2011 and the date of redemption of all of our 10\% Cumulative Perpetual Preferred Stock, Series G (Series G Preferred Stock), whether or not he continues to be employed by us, (i) he will continue to satisfy the share retention requirements described in the preceding paragraph and (ii) he, his spouse and any of their estate planning vehicles will not dispose of more than $10 \%$ of the aggregate number of shares of Common Stock that he, his spouse and any such estate planning vehicles beneficially owned on September 28, 2008.

Goldman Sachs Group, Inc., Definitive Proxy Statement, supra note 52, at 16. Buffett imposed a similar requirement when investing in General Electric. See Rachel Layne, GE's Immelt Waived Bonus Pay After 2008 Profit Drop, BlOOMBERG, Feb. 18, 2009, available at http:/ / www.bloomberg.com/apps/news?pid=20601087\&sid=aSAtrN029FQY ("Immelt, who has always exceeded a requirement to hold shares valued at six times his salary in stock, agreed in October to hold at least 90 percent of the shares he already owns as a condition of Warren Buffett's Berkshire Hathaway Inc.'s investment in the company.”). 
thousand companies appear to have illegally backdated the grants of managers' options. ${ }^{54}$ Such backdating both increased and obscured the value of executives' equity-based compensation. Most of this backdating took place before the Sarbanes-Oxley Act of $2002,{ }^{55}$ which changed reporting requirements to make backdating more difficult. However, option-grant backdating continued even after SarbanesOxley, in open violation of that statute's reporting provisions. ${ }^{56}$ Fortunately, heightened media and regulatory scrutiny will likely reduce the amount of option-grant backdating going forward and may well put an end to this practice.

However, even if option-grant backdating is eliminated, firms must address two other problematic practices surrounding equity grants. In particular, firms must ensure that executives do not use inside information to game the timing of equity grants to shift value from public shareholders to themselves (so-called "springloading"). Firms must also reduce executives' ability to affect the stock price around grants through their control over the flow of information from the firm.

\section{The Timing of Equity Grants}

Executives can make themselves better off by using inside information to time their option and restricted stock grants. In particular, equity grants can be awarded when executives know that good news will emerge in the near future. This practice of informed grant timing is called "springloading."

Executives have particularly strong incentives to springload option grants. Public company executives frequently receive large, multiyear option grants—sometimes totaling tens or hundreds of millions of

\footnotetext{
${ }^{54}$ See Lucian Bebchuk et al., Lucky CEOs and Lucky Directors, J. FIN. (forthcoming) (manuscript at 6-9, on file with author) (finding that before Sarbanes-Oxley, fifty-five percent of "lucky grant events" were due to opportunistic timing); Jesse M. Fried, $O p$ tion Backdating and Its Implications, 65 WASH. \& LEE L. REV. 853, 863-64 (2008) (noting studies that suggest that over 2000 firms backdated executive stock option grants between 1996 and 2005). Executives were further enriched by the backdating of stock option exercises, as well as by the backdating of stock option grants to nonexecutive employees. See id. at 871-80 (explaining how these practices can boost executives' pay in a way hidden from shareholders).

${ }^{55}$ Pub. L. No. 107-204, 116 Stat. 745 (codified as amended in scattered sections of $11,15,18,28$, and 29 U.S.C.).

${ }^{56}$ See Fried, supra note 54, at 882-83 (explaining that "thousands of firms continued to engage in secret option backdating" even after Sarbanes-Oxley and the accompanying stock exchange reforms).
} 
dollars-on a specific grant date. ${ }^{57}$ Most of these option grants are issued "at-the-money": the strike price is set to the market price on the grant date. The value of the option grant critically depends on the strike price; a lower strike price increases the value of the option. Thus, an executive who knows that good news will emerge shortly, boosting the stock price, can benefit by accelerating an option grant so that the strike price is set to the (low) current price.

To illustrate how springloading benefits executives, suppose $\mathrm{ABC}$ Corporation's stock is trading at $\$ 90$ on Monday. The board is planning to issue at-the-money options on Friday. However, the board knows that good news will emerge by Friday, boosting the stock price to $\$ 100$ on that date. Instead of waiting until Friday to issue an at-themoney option with a strike price of $\$ 100$, the board issues an at-themoney option on Monday with a strike price of $\$ 90$. By Friday, when the board was originally planning to issue the option, the stock price is $\$ 100$, and the Monday-issued option is already $\$ 10$ "in-the-money": the strike price is $\$ 10$ below the market price. Essentially, springloading is economically equivalent to giving an executive an in-the-money option disguised as an at-the-money option. ${ }^{58}$

A widely reported instance of springloading occurred at the medical-device firm Cyberonics in 2004. The board approved stock option grants for top executives one evening, several hours after the company had received positive news about the regulatory prospects for one of its products. The next day, Cyberonics' stock price took off; so did the value of the options. The company's chair and CEO "earned" instant paper profits of $\$ 2.3$ million. $^{59}$

Cyberonics was not an isolated incident. Rather, according to a recent empirical study by Rik Sen, widespread springloading continued even after Sarbanes-Oxley was enacted. ${ }^{60}$ Sen's study examined option

\footnotetext{
${ }^{57}$ For example, in 2001 Apple gave Steve Jobs a single option grant with a BlackScholes value of around $\$ 500$ million. See BEBCHUK \& FRIED, supra note 1, at 161 .

${ }^{58}$ In that respect, springloading is similar to grant backdating, which also disguises in-the-money options as at-the-money options. See Fried, supra note 54, at 859-61.

${ }^{59}$ Barnaby J. Feder, Questions Raised on Another Chief's Stock Options, N.Y. TIMES, June 9, 2006, at C1.

${ }^{60}$ See Rik Sen, The Returns to Spring-Loading 2, 10-14 (Mar. 2009) (unpublished manuscript), available at http://ssrn.com/abstract=1102639 (finding widespread springloading in a sample of public firms between 2002 and 2006); see also Daniel W. Collins et al., The Effect of the Sarbanes-Oxley Act on the Timing Manipulation of CEO Stock Option Awards 11-17 (Nov. 16, 2005) (unpublished manuscript), available at http://ssrn.com/abstract=850564 (examining option grants in public firms between 1999 and 2003, reporting that there are positive abnormal returns in the forty-day pe-
} 
grants by public companies between September 2002 and March 2006, focusing on "unscheduled" option grants-those that did not appear to be made according to the normal grant schedule and were thus most likely to be springloaded. ${ }^{61}$ Sen found that, following such grants, the stock experienced $1.1 \%$ monthly abnormal (i.e., market-adjusted) returns, providing strong evidence that, in many cases, the stock was underpriced relative to its actual value on the grant date. ${ }^{62}$

Boards seeking to favor executives may also have an incentive to springload restricted stock grants. For example, if the value of the grant is fixed, springloading will allow the firm to give the executives more shares, boosting their overall compensation. Suppose again that ABC Corporation's stock is trading at $\$ 90$ per share on Monday, but the board knows that good news will emerge on Friday, boosting the stock price to $\$ 100$ per share. Suppose also that ABC's CEO is entitled to receive $\$ 9$ million worth of stock this year, valued at the current trading price. If the board grants the CEO the stock on Friday, she will receive 90,000 shares ( $\$ 9$ million divided by $\$ 100$ per share). If the board grants the CEO the stock on Monday, she will receive 100,000 shares ( $\$ 9$ million divided by $\$ 90$ per share). Springloading the restricted stock grant in this example thus gives the CEO an additional 10,000 shares worth $\$ 100$ each, or an extra $\$ 1$ million. ${ }^{63}$

Executives' ability to benefit from springloading options and restricted stock can be substantially reduced by granting both types of equity on fixed dates throughout the firm's calendar. Such dates might include (1) the first regularly scheduled compensation-committee meeting following an executive's initial hire; (2) the meeting of the compensation committee accompanying the company's annual meeting of shareholders; or (3) the regularly scheduled meeting of the compensation committee for the first quarter. A number of companies have already adopted this approach. For example, Juniper Networks and other companies accused of backdating stock options have, as part of their settlements of backdating-related claims, agreed to restrict the

riod following unscheduled option grants after Sarbanes-Oxley, and concluding that this likely reflects the award of options before good news).

${ }^{61}$ Sen, supra note 60 , at $12-13$.

${ }^{62} I d$. at 21.

${ }^{63}$ If the number of shares granted is fixed, springloading the stock grant may still benefit an executive in two ways. First, by enabling the firm to report less compensation for the executive, springloading is likely to reduce shareholder outrage over the amount of the executive's pay. Second, to the extent springloading lowers reported compensation expense and boosts reported earnings, it may enable the executive to receive larger earnings-based cash bonuses. 
dates on which the firm can grant options and restricted stock to executives. ${ }^{64}$ Other companies would benefit from following their example.

This brings us to the following principle:

PRINCIPLE 5: The timing of equity awards to executives should not be discretionary. Rather, such grants should be made only on prespecified dates.

\section{Stock-Price Manipulation Around Equity Grants}

Even if equity grant dates are fixed in advance, executives may be able to game equity awards at the front end by influencing corporate disclosures prior to the equity award. For example, executives may have an interest in accelerating the release of negative information before the equity award and delaying disclosures about positive developments until after the award. Artificially lowering the stock price in this manner can benefit executives, whether their grant consists of options or restricted stock.

Executives have the strongest incentive to manipulate the stock price around option grants. A lower grant-date price reduces the exercise price of at-the-money options, boosting managers' profits when the options are later exercised. Thus, even if managers cannot control the timing of option grants, they can profit by depressing the grant-date price, thereby getting options with exercise prices that are, on average, below the "true" value of the stock at the grant date. ${ }^{65}$ Like the springloading described above, such manipulation disguises in-the-money options as at-the-money options.

A number of studies find a systematic connection between option grants and corporate disclosures. Specifically, companies are more likely to release bad news, and less likely to release good news, just before options are granted. ${ }^{66}$ One study examines companies that have

${ }^{64}$ See, e.g., Juniper Networks, Inc., Definitive Proxy Statement (Schedule 14A), at 46 (Apr. 10, 2009) ("Annual equity awards to Section 16 officers are generally scheduled to be approved at a meeting of the Compensation Committee in the first quarter after the Q4 earnings announcement and prior to March 1. The annual grants to Section 16 officers are also generally scheduled to be effective on the third Friday of the month if the meeting approving such grants occurs on or before such date.").

${ }^{65}$ See, e.g., Terry Baker et al., Incentives and Opportunities to Manage Earnings Around Option Grants, CONTEMP. ACCT. RES. (forthcoming) (manuscript at 22-23), available at http://ssrn.com/abstract=1124088 (reporting that managers can use discretionary financial accounting measures to lower option grant-date stock prices and thereby reduce option exercise prices).

${ }^{66}$ David Aboody \& Ron Kasznik, CEO Stock Option Awards and the Timing of Corporate Voluntary Disclosures, 29 J. ACCT. \& ECON. 73, 93 (2000) (“[F]irms whose CEOs re- 
scheduled option grant dates-that is, companies whose managers do not appear to control the timing of their option grants. ${ }^{67}$ It finds that managers time voluntary disclosures both to reduce the stock price before getting their at-the-money options and to boost the stock price afterward. ${ }^{68}$ Another study suggests that executives deliberately miss earnings targets to cause the stock price to drop before large option grants. In particular, managers boost income-decreasing accruals prior to stock option grants. ${ }^{69}$

An executive about to receive a restricted stock grant may also have an incentive to lower the stock price on the grant date. For example, if the value of the grant is fixed and the number of shares is variable, depressing the grant-date stock price enables the executive to receive more shares, boosting her compensation directly. If the executive can reduce the stock price by (say) ten percent, she will get approximately ten percent more shares in the option grant.

Firms could eliminate the incentive to manipulate the stock price around the grant of stock options or restricted stock by setting the exercise price to a price other than the grant-date stock price. For example, consider an executive who is promised that, over each of $X$ years, $Y$ options will be granted each year. Instead of setting the exercise price to the stock price on the grant date each year-a price that could be manipulated-the exercise price could be set to the stock price at the time of hiring.

Similarly, the incentive to manipulate the stock price around the grant date of restricted stock would be reduced if the promised grants of restricted stock each year were specified in terms of the number of shares, rather than their value at the time of the grant. Otherwise, the executive may have an incentive to depress the stock price around the grant date to boost the number of shares received. ${ }^{70}$ This brings us to yet another principle:

ceive options shortly before earnings announcements are more likely to issue bad news forecasts, and less likely to issue good news forecasts, than are firms whose CEOs receive their awards only after earnings announcements.").

${ }^{67}$ Id. at 82 .

${ }^{68} I d$. at 74-75.

${ }^{69}$ See Mary Lea McAnally et al., Executive Stock Options, Missed Earnings Targets and Earnings Management 3-6 (May 24, 2007) (unpublished manuscript), available at http://ssrn.com/abstract=925584 ("[M]anagers with larger subsequent grants are more likely to miss annual earnings targets even after controlling for conflicting incentives and other factors that potentially influence the decision to avoid missing an earnings target.").

${ }^{70}$ The executive may still have an incentive to manipulate the grant-date stock price around fixed-number restricted stock grants. Depressing the stock price could 
PRINCIPLE 6: To reduce the potential for gaming, the terms and amount of posthiring equity awards should not be based on the grant-date stock price.

\section{B. The Back End}

Our analysis in Part I emphasized the importance of requiring executives to hold stock for the long term. We explained why it was desirable to impose both grant-based and aggregate limitations on unwinding. These restrictions would limit the amount of equity that executives could unload each year. We now focus more closely on the exact manner by which executives should be permitted to cash out the equity they are free to unwind in a given year.

\section{Gaming Problems at the Back End}

Currently, executives have considerable discretion over when they sell their shares, including stock received through the exercise of options. As we explain below, giving executives such freedom over the precise timing of unwinding after unblocking could give rise to two types of problems if the unblocking occurs while the executives are still in office: they may use inside information to time equity sales and manipulate the stock price prior to such sales.

\section{a. Using Inside Information to Time Equity Unwinding}

Executives who are free to decide when to sell their shares may use inside information to time their sales, selling before bad news emerges and the stock price declines. For example, executives tend to exercise their options and sell the underlying stock before earnings deteriorate and the price of the stock underperforms the market. ${ }^{71}$ These findings help to explain the body of evidence indicating that

provide two benefits to the executive. First, it would allow the firm to report less compensation for the executive, reducing the risk of shareholder outrage. Second, it would lower the firm's compensation expense, boosting reported earnings and those elements of the executive's pay package tied to earnings. Thus, even if the firm uses fixed-number restricted stock grants, the executive can benefit from a lower grant-date stock price. But we believe those benefits are smaller and less direct than the benefits from lowering the grant-date stock price around fixed-value restricted stock grants.

${ }^{71}$ See Jennifer N. Carpenter \& Barbara Remmers, Executive Stock Option Exercises and Inside Information, 74 J. BUS. 513, 531-32 (2001) (finding empirical evidence that top managers at small firms may time the exercise of their options based on inside information); Bin Ke et al., What Insiders Know About Future Earnings and How They Use It: Evidence from Insider Trades, 35 J. ACCT. \& ECON. 315, 342-43 (2003) (finding evidence that insiders time their trades well in advance of negative news to avoid the appearance of trading on inside information). 
managers make considerable "abnormal" profits-that is, abovemarket returns-when trading in their own firms' stock. ${ }^{72}$

The previous decade has provided many dramatic examples of insiders unloading shares before their firms' stock prices plunged. A study published by Fortune in September 2002 examined executive trading in the shares of publicly held firms that had reached a market capitalization of at least $\$ 400$ million and whose shares subsequently had fallen at least seventy-five percent. ${ }^{73}$ The firms were ranked by the amount of executive sales. At the top twenty-five firms, 466 executives collectively sold $\$ 23$ billion before their stock plummeted. ${ }^{74}$

\section{b. Stock-Price Manipulation Around Unwinding}

Whether or not inside information motivates executives' stock sales, executives have an incentive to manipulate information to boost the stock price before selling. In fact, many studies have found a connection between the amount of executive selling and earnings manipulation-both legal and illegal. For example, firms in which annual option exercises are particularly high tend to have higher discretionary accruals (and, therefore, higher reported earnings) in those years and lower discretionary accruals and earnings in the subsequent two years. ${ }^{75}$ Additionally, firms that fraudulently misstate their earnings tend to have more insider selling activity-measured by the number of transactions, the number of shares sold, or the dollar amount of shares sold. ${ }^{76}$

\footnotetext{
${ }^{72}$ See Fried, supra note 22, at 322-23 (explaining that corporate insiders consistently earn excess returns when trading in their own shares).

${ }^{73}$ Mark Gimein, You Bought. They Sold., ForTune, Sept. 2, 2002, at 64, 65.

${ }^{74}$ Id. at 66.

75 See Eli Bartov \& Partha Mohanram, Private Information, Earnings Manipulations, and Executive Stock-Option Exercises, 79 ACCT. REv. 889, 909 (2004) (finding improved earnings performance before executives exercise options and deteriorating earnings performance after option exercises, which suggests that top-level management times option exercises based on inside information about future earnings).

${ }^{76}$ See Scott L. Summers \& John T. Sweeney, Fraudulently Misstated Financial Statements and Insider Trading: An Empirical Analysis, 73 ACCT. REV. 131, 144 (1998) ("[I]nsiders in companies where fraud is found reduce their net position in the entity's stock by engaging in significant selling activity, regardless of whether selling activity is measured by dollars of shares sold, number of shares sold or number of selling transactions."); see also Messod D. Beneish, Incentives and Penalties Related to Earnings Overstatements that Violate GAAP, 74 ACCT. REV. 425, 454 (1999) (finding that managers of firms whose earnings were overstated tended to sell at a high rate before the overstatements were corrected); Natasha Burns \& Simi Kedia, The Impact of Performance-Based Compensation on Misreporting, 79 J. Fin. ECON. 35, 63 (2006) (finding that top managers of firms that experienced accounting irregularities and were subsequently subject to SEC enforcement actions had exercised their options in the preceding period at a higher rate than top managers of
} 
The passage of the Sarbanes-Oxley Act of 2002, which was motivated in part by the evidence of widespread earnings manipulation in the 1990s, has reduced-but not eliminated-executives' ability to misreport earnings. For example, in 2006, four years into the postSarbanes-Oxley era, the number of earnings restatements filed by public companies reached an all-time record: $1876 .{ }^{77}$ Thus, Sarbanes-Oxley does not appear to have prevented managers from misreporting. ${ }^{78}$

Moreover, Sarbanes-Oxley fails to reach one of the most harmful forms of earnings manipulation: "real-earnings management," the practice of making business decisions for the purpose of boosting short-term accounting results, rather than maximizing the size of the corporate pie. For example, executives can prop up short-term earnings by postponing desirable investments or by accelerating revenuegenerating transactions that would create more long-term value if they were delayed.

Because real-earnings management does not violate the accounting rules as long as a firm's financial statements properly reflect all of the relevant transactions, Sarbanes-Oxley cannot prevent or deter it. Indeed, such manipulation appears to have increased after SarbanesOxley. ${ }^{79}$ Thus, we can expect executives who sell large blocks of stock to continue manipulating the stock price around these sales-through both misreporting and real-earnings management—to increase their trading profits.

other firms); Shane A. Johnson et al., Managerial Incentives and Corporate Fraud: The Sources of the Incentives Matter 27 (Feb. 29, 2008) (unpublished manuscript), available at http://ssrn.com/abstract=395960 ("[F] raud executives generate greater payoffs than control executives during the fraud periods by selling stock and exercising options, with the overwhelming majority of the payoffs coming from stock sales.").

77 See David Reilly, Restatements Still Bedevil Firms, WALL ST. J., Feb. 12, 2007, at C7.

${ }^{78}$ Section 304 of the Sarbanes-Oxley Act of 2002 requires the CEO and CFO of a firm forced to restate earnings to return to the firm any bonus or other incentive or equity-based compensation received (or profits from stock sold) within twelve months of the misleading financial statement. 15 U.S.C. $\$ 7243$ (2006). Thus, some may have hoped that Sarbanes-Oxley would reduce not only executives' ability to manipulate earnings but also their incentive to do so. However, this "clawback" provision applies only in special circumstances involving "misconduct," and it has been invoked mainly in cases where executives were convicted of criminal fraud. See Jerry W. Markham, Regulating Excessive Executive Compensation-Why Bother?, 2 J. BuS. \& TECH. L. 277, 299 (2007) ("Unless convicted criminally, executives . . . usually were able to keep their bonuses.”). Thus, section 304 is unlikely to deter misreporting in run-of-the-mill cases not involving criminal fraud.

${ }^{79}$ See Daniel A. Cohen et al., Real and Accrual-Based Earnings Management in the Pre- and Post-Sarbanes Oxley Periods 33-34 (June 2007) (unpublished manuscript), available at http://ssrn.com/abstract=813088 (finding that the level of real-earnings management activities "increased significantly" after the passage of Sarbanes-Oxley). 


\section{Addressing Gaming Problems at the Back End}

Both forms of back-end gaming-executives' use of inside information to time their sales and price manipulation to boost their trading profits-hurt public investors. Each extra dollar pocketed by managers comes at the expense of public shareholders. More importantly, executives' ability to sell on inside information and inflate the short-term stock price before unwinding can reduce the size of the total corporate pie by distorting managers' operational decisions ex ante. The indirect costs to public investors of such distortions could be far larger than the value directly captured by executives.

Fortunately, firms can reduce both forms of back-end gaming. In particular, firms should limit the extent to which the payoff from stock sales depends on a single stock price. Rather, as we explain below, the payoff should be based on the average stock price over a significant period of time. In addition, executives should be required either to disclose their sales several months before they begin to unwind their equity or to unload their stock under an automatic schedule created when the equity is granted.

\section{a. Average-Price Payoffs}

Currently, executives can choose the precise date on which and the price at which they will sell a large amount of stock. This allows executives to use inside information to time the sale when the stock price is high and about to decline. Moreover, whatever the motive for the sale, executives about to unload a large amount of stock have an incentive to manipulate the stock price to increase their profits from the sale. We present two approaches to tying payoffs to the average stock price- "immediate cash-out" and "gradual cash-out"-and show that either approach would reduce both types of back-end gaming.

Under the immediate cash-out approach, executives would be permitted to liquidate large amounts of "unblocked" equity by selling the equity to the firm at the current market price; a certain number of months later ( $X$ months), the transaction price would be retroactively adjusted to reflect the average price of the stock over those $X$ months. To illustrate, suppose an executive of ABC Corporation decides to sell 100,000 shares of ABC stock, then trading at $\$ 10$ per share. The executive would transfer the stock to $\mathrm{ABC}$ in exchange for an immediate payment of $\$ 1$ million $(100,000$ shares at $\$ 10$ per share). The firm would track the average closing price over the next $X$ months. If the average closing price of the stock exceeded $\$ 10$, the executive would 
receive an additional payout at the end of $X$ months. Conversely, if the average monthly closing price fell short of $\$ 10$, the executive would be required to return some of the $\$ 1$ million to $\mathrm{ABC}$ at the end of $X$ months.

Alternatively, an executive wishing to unload unblocked equity could be permitted to sell the shares in the market only gradually, according to a prespecified, automatic plan. Consider again the executive of ABC Corporation. If she decided to sell 100,000 shares of company stock, she would be permitted to sell $100,000 / X$ shares on (say) the first trading day of each of the following $X$ months. Under this gradual cash-out approach, the executive would be required to execute all planned trades; she could not back out of them if she later obtained inside information suggesting that she would be better off not selling the stock.

This gradual cash-out approach is similar to the widely used 10b5-1 trading plans, but there is an important difference. An executive can terminate a 10b5-1 plan midstream if she later obtains inside information suggesting that she is better off keeping her stock-thereby enabling her to make higher trading profits at the expense of public shareholders. ${ }^{80}$ Under our proposed approach, once executives announce sales, they must effect them according to the terms of the previously specified plan. They may not terminate the sales midstream. ${ }^{81}$

By tying executives' equity payoff to the stock's average price over a long period of time, both the immediate cash-out approach and the gradual cash-out approach would make it more difficult for executives to use inside information to time their stock sales. An executive could, of course, initiate an unwinding based upon inside information indicating that the stock price is likely to drop. But the payout from each unwinding would be a function of the average stock price over a

${ }^{80}$ See Jesse M. Fried, Essay, Insider Abstention, 113 YALE L.J. 455, 486-91 (2003) ("[W] hen an insider enters the SEC's safe harbor by employing a prearranged plan, the ability to terminate the plan while aware of material nonpublic information permits her to use material nonpublic information to increase her trading profits.").

${ }^{81}$ The gradual cash-out approach is different from the immediate cash-out approach in two respects. First, it is administratively simpler. The executive unloads her stock directly into the market on specified dates; the prices on those dates determine the payoff. Unlike the immediate cash-out approach, the firm need not effect the initial transaction and then, $X$ months later, determine the amount to be transferred to or from the executive to ensure that her net payoff equals the average stock price over the $X$-month period. Second, unlike the immediate cash-out approach, the executive must wait $X$ months to fully liquidate the equity being unwound. The administrative simplicity of the gradual cash-out approach thus comes at the expense of higher liquidity costs for the executive. 
period of $X$ months. To the extent that the inside information emerges and becomes incorporated into the stock price before the $X$-month period ends, the payoff from the unwinding would be lower than under current practice, which enables an executive to dump all of her stock at a single price.

Similarly, both the immediate and gradual cash-out approaches would reduce executives' incentives to manipulate the short-term stock price prior to unwinding. Such manipulation might affect the stock price at the beginning of the $X$-month period. But if the specified period is sufficiently long, any temporary boost in the price would be at least partially reversed (and perhaps followed by an offsetting dip) later in the $X$-month period, thereby reducing the net payoff to the executive from manipulating the stock price (and perhaps eliminating it altogether).

\section{b. The Need for Additional Steps}

The immediate and gradual cash-out approaches described above would reduce executives' ability to profit from inside information by tying payoffs to the average stock price over a specified period. However, they would not eliminate executives' ability to use inside information to time their sales. Executives often have inside information bearing on the performance of the stock price many months in advance. ${ }^{82}$ Thus, tying executives' payoffs to the average stock price over a certain period ( $X$ months) may not affect their ability to sell on inside information if this period is relatively short. Consider an executive of a firm using a five-month cash-out period to determine payoffs, who has inside information suggesting the stock price will fall in six months. If this executive unwinds her stock under either an immediate or gradual cash-out arrangement, she will receive more for the stock than it is actually worth.

Even if the cash-out period is relatively long, the use of average prices during this period would merely reduce-but not eliminateexecutives' ability to sell on inside information. Consider again the executive who has inside information suggesting that the stock price will fall in six months. Suppose now that the cash-out period is one year. If the insider initiates an unwinding, the stock price during the

${ }^{82}$ See Fried, supra note 22, at 346 ("[I] nsiders often have access to important information months before it is announced...."); Ke et al., supra note 71, at 317 (reporting that insiders trade on accounting information as long as two years prior to the disclosure). 
first six months of the twelve-month period will be higher than its true value; in the second six months, the stock price will (let us suppose) reflect its true value. The average stock price over the entire twelvemonth period will thus be higher than its true value, and the executive will be able to generate more proceeds from selling the stock if she begins unwinding now rather than later.

Indeed, the above analysis may help explain why 10b5-1 plans have not been that effective at reducing insider trading profits. One study of executive trading in more than 1200 firms during the fiveyear period ending in December 2005 found that insiders regularly use 10b5-1 plans to sell on inside information. ${ }^{83}$ In fact, the study found that executives using 10b5-1 plans were more likely to sell on valuable inside information than executives not using such plans. ${ }^{84}$

To further reduce executives' ability to sell on inside information, firms should take one of the additional steps we describe below: either (1) require executives to disclose their intended sales far in advance or (2) use a "hands-off" arrangement under which the cash-out dates are specified when the equity is granted, leaving executives with no discretion over when their stock is sold.

\section{c. Pretrading Disclosure}

If executives have any discretion over when they cash out their equity, they should be required to disclose their intended unwinding in advance, a proposal one of us made more than ten years ago. ${ }^{85}$ Such advance disclosure, coupled with average-price payoffs, would further reduce executives' ability to profit from the back-end gaming of insider trading.

To begin, advance disclosure would give any inside information on which the executive is trading more time to emerge and become incorporated into the stock price. The average stock price during the payoff period would thus more accurately reflect the actual value of

${ }^{83}$ See Alan D. Jagolinzer, SEC Rule 10b5-1 and Insiders' Strategic Trade, 55 MGMT. SCI. 224, 232-35 (2009) (showing that trades by executives participating in 10b5-1 plans are followed by abnormal stock price declines).

${ }^{84}$ See id. at 229-32.

${ }^{85}$ See Fried, supra note 22, at 349-53 (arguing for a "pretrading disclosure rule," under which the corporate insider could not submit an order to buy or sell shares in the company without first giving notice in advance). For a more condensed version of the proposal, see Jesse M. Fried, Advance Disclosure of Managers' Stock Trades: A Proposal to Improve Executive Compensation, ECONOMISTS' VOICE, Nov. 2006, http://www.bepress.com/ ev/vol3/iss8/art7. 
the stock, improving the link between pay and performance. For example, suppose that the average price used to determine the payoff to the unwinding executive is based on a five-month period. If the executive were required to disclose the intended unwinding $X$ months before the five-month period began, any inside information on which the executive was trading would have $X$ more months to emerge and affect the stock price, making it more likely that the stock price used to calculate the payoff to the executive would be accurate.

In addition, the disclosure of large or otherwise unusual sale orders would intensify scrutiny of the firm and its managers. An unusually large sale order, for example, would signal the possibility that the executive knows bad news is likely to emerge. If further investigation suggests that the stock is overpriced, market participants will drive the price down even before the payoff period begins, reducing the total proceeds from the unwinding.

Finally, an executive who sells on inside information is likely to be forced to make future sales at lower prices, even if those future sales are driven by liquidity or diversification reasons. Currently, market professionals analyze insiders' posttransaction trading reports to identify executives whose purchases and sales predict large price movements. These executives' trades are used to figure out whether a particular stock is overpriced or underpriced. Managers with nonpredictive trades attract far less attention. Under advance disclosure, executives who sell before large price declines will subsequently face larger adjustments than executives who do not, regardless of their motives for these future trades. These future adjustments should further reduce managers' insider trading profits and their incentives to trade on inside information in the first place.

We are aware of only one firm, Ameritrade, that has ever indicated it would impose a pretrading disclosure requirement on its executives. ${ }^{86}$ In early February 1999, ten Ameritrade insiders sold tens of thousands of shares as the stock price peaked shortly before a sharp decline. To mollify angry shareholders, Ameritrade announced that, in the future, it would require insiders to announce in advance any plans to sell shares, including the number of shares they planned to sell. Ameritrade's chairman and co-CEO explained, "I feel that instituting a policy which ensures [that shareholders] know in advance when insiders in-

${ }^{86}$ See BeBChUK \& FRIED, supra note 1, at 180-81 (citing Randall Smith \& Danielle Sessa, Ameritrade Says Insiders' Sales Must Now Be Announced First, WAll ST. J., Mar. 17, 1999, at C1). 
tend to sell stock is simply the right thing to do." ${ }^{87}$ However, Ameritrade quietly canceled the policy before any executive traded. ${ }^{88}$

\section{d. "Hands-Off" Arrangements}

While pretrading disclosure would further reduce executives' ability to profit from their access to inside information, a "hands-off" arrangement that left executives no discretion over when their equity is cashed out could eliminate such profits entirely. ${ }^{89}$ Under this arrangement, restricted stock and stock options would be cashed out according to a fixed, gradual, and preannounced schedule set when the equity was granted. At least one firm has adopted the "hands-off" approach to its option compensation. In 2007, Level 3 Communications filed a compensation plan with the SEC under which executives' options are cash settled according to a predisclosed gradual schedule. ${ }^{90}$

Hands-off equity leaves executives no discretion as to when they may unwind their equity. As a result, executives compensated with such equity cannot use inside information to decide when to sell. Hands-off equity thus eliminates all the insider trading profits that executives make in connection with stock sales. There is no other arrangement as effective at reducing executives' insider trading profits.

Some may be concerned that hands-off arrangements would undesirably reduce executive equity holdings. But if a corporate board identifies the desired level of executive equity ownership ex ante, it can design the hands-off plan to ensure that the executive always retains that amount of equity. Should changing circumstances make the optimal level of equity ownership higher than had been expected, the board can arrange for the executive to acquire additional equity (for example, by reducing cash compensation and issuing more hands-off equity). Indeed, properly structured, hands-off arrangements could ensure that executives always have sufficient equity. ${ }^{91}$

${ }^{87}$ Id.

${ }^{88}$ See id. at $180-81$.

89 See Jesse M. Fried, Hands-Off Options, 61 VAND. L. REV. 453, 468-70 (2008) (proposing "hands-off" options as a means of reducing the costs to shareholders that arise when executives have the freedom to choose when to unwind their equity).

90 See Level 3 Commc'ns, Definitive Proxy Statement (Schedule 14A), at 19 (Apr. 18, 2007) (" $[\mathrm{R}]$ ecipients of these [stock-indexed securities] will not be able to voluntarily exercise [them] as they will settle automatically with value on the third anniversary of the date of the award or expire without value on that date.").

${ }^{91}$ In addition to ensuring that executives retain a desirable amount of equity, hands-off equity might yield several collateral benefits. For example, the practice would encourage managers to focus on running the business rather than timing their trades. 
This brings us to our next principle:

PRINCIPLE 7: To the extent that executives have discretion over the timing of sales of equity incentives not subject to unwinding limitations, executives should announce sales in advance. Alternatively, the unloading of executives' equity incentives should be effected according to a prespecified schedule put in place when the equity is originally granted.

\section{Limitations On HEDGing AND DERIVATIVE TRANSACTIONS}

The preceding Parts have discussed how equity-based compensation should be designed to tie executive payoffs from equity-based compensation to long-term shareholder value. For these arrangements to produce their intended benefits, however, it is essential that executives not be able to use hedging and derivative transactions to undermine or circumvent them. This Part discusses the limitations on such transactions that are important for firms to adopt.

As we highlighted in Pay Without Performance, standard pay arrangements have commonly failed to restrict the use of financial instruments that can weaken or eliminate entirely the incentive effects of equity-based instruments awarded as part of compensation arrangements. ${ }^{92}$ Indeed, standard arrangements have failed to prohibit executives from entering into hedging transactions with respect to their own firms' stock. A study by Stewart Schwab and Randall Thomas of 375 employment contracts collected by the Corporate Library found that none restricted the CEO from hedging her option grants. ${ }^{93}$

A recent empirical study by Bettis, Bizjak, and Kalpathy confirms the significance of the problem we highlighted in Pay Without Performance. $^{94}$ The study examines executives' disclosures to identify cases

It would also reduce arbitrary differences in executives' payoffs due to luck in timing transactions, increasing pay equity within the management team.

${ }^{92}$ See BEBCHUK \& FRIED, supra note 1, at 176-77 (noting that boards often do not even request such restrictions).

${ }^{93}$ Stewart J. Schwab \& Randall S. Thomas, An Empirical Analysis of CEO Employment Contracts: What Do Top Executives Bargain For?, 63 WASH. \& LEE L. REv. 231, 240, 264 (2006).

${ }^{94}$ Carr Bettis, John Bizjak \& Swaminathan Kalpathy, Insiders' Use of Hedging Instruments: An Empirical Examination (Mar. 2010) (unpublished manuscript), available at http://ssrn.com/abstract=1364810. For an earlier study on the prevalence of hedging instruments, see J. Carr Bettis, John M. Bizjak \& Michael L. Lemmon, Managerial Ownership, Incentive Contracting, and the Use of Zero-Cost Collars and Equity Swaps by Corporate Insiders, 36 J. Fin. \& QUANTITATIVE ANALYSIS 345 (2001). 
in which executives hedged their stock positions in their firms. ${ }^{95}$ The study finds that, between 1996 and 2006, more than 1000 insiders hedged their stock positions. ${ }^{96}$ The average level of ownership hedged through the most common forms of hedging transactions was significant, around thirty percent. ${ }^{97}$

The Bettis, Bizjak, and Kalpathy study found that hedging transactions were preceded by large abnormal positive price returns and often followed by large negative abnormal returns. ${ }^{98}$ This pattern is consistent with executives profiting by either using inside information to time their hedging transactions or using their influence over corporate disclosure decisions to boost the price before entering the hedging transactions. The researchers distinguish between hedging that is motivated by such use of inside information and influence over disclosures, which they view unfavorably, and hedging motivated by a desire to diversify risk, which they appear to view as legitimate. ${ }^{99}$ But hedging that is motivated solely by a desire to diversify risks is also problematic and should be prevented.

Consider a board that awards an executive one million shares worth $\$ 10$ each at the time of the award. Suppose that the shares will vest at the end of the year and then be subject to restrictions on unloading that will prevent the executive from cashing out the shares for an additional three years. The award is designed to provide the executive, during the four subsequent years, with an incentive to increase the longterm value of the firm's shares. Suppose also that the executive is not subject to any limitations on hedging and derivative transactions and that immediately following receipt of the award the executive sells short one million of the company's shares (or enters into any other economically equivalent derivative transaction), pocketing $\$ 10$ million. The executive then waits four years and delivers the now freely transferable shares awarded by the company to close the short position.

In this case, even though the company has awarded stock that the executive cannot unwind for four years, the executive will not have any economic exposure to changes in the firm's value during the four years following the equity grant. The executive will be in the same situation that she would have been in had the board granted her a $\$ 10$ million

\footnotetext{
${ }^{95}$ Bettis, Bizjack \& Kalpathy, supra note 94 , at 3.

${ }^{96} I d$. at 11 .

${ }^{97} I d$. at 13.

${ }^{98} I d$. at 20-21.

${ }^{99}$ See id. at 2 n.5 (discussing arguments that hedging transactions are "benign and are used for diversification").
} 
cash payment rather than an equity award with a grant-date value of $\$ 10$ million. Converting the $\$ 10$ million equity award into a fixed $\$ 10$ million cash payment enables the executive to avoid uncertainty and riskbearing costs. Thus, even if the executive does not have information suggesting that the value of the firm's stock will fall below $\$ 10$ a share, she may well benefit from entering into this hedging transaction.

From the perspective of the firm and its shareholders, however, there is no reason to allow the executive to convert the $\$ 10$ million equity award into a $\$ 10$ million cash payment. The board could have granted the executive a $\$ 10$ million cash payment in lieu of the $\$ 10$ million equity award, but chose not to do so. This choice was presumably based on a desire to tie the executive's compensation to her performance and thereby provide desirable incentives to increase shareholder value. Indeed, the use of equity instruments as the means of compensation might have led the board to offer a higher level of pay than if the executive had been paid only in cash. Given the board's choice of an equity-based pay structure and its setting of pay levels in light of this chosen structure, the executive should not be permitted to change the structure unilaterally by using hedging and derivative transactions. ${ }^{100}$

The problem of executives' use of hedging and derivative transactions is likely to become even more important in the future. As we discussed, past pay arrangements have commonly allowed executives to freely unload all vested equity-based awards, and concerns about hedging and derivatives have thus been limited to their use in undoing the effects of awarded, but not yet vested, options and shares. If firms begin to limit the unloading of vested equity awards, along the lines we have proposed or otherwise, the set of circumstances in which executives have incentives to use hedges and derivatives to undo the effects of these arrangements will expand substantially.

In other words, the adoption of restrictions on the unwinding of equity-based awards, as well as the adoption of restrictions aimed at preventing gaming, make it all the more important limit the use of hedging and derivative transactions by top executives. Without such limitations, the restrictions on unloading and gaming can easily be undone. No matter how strong the restrictions and limitations are in theory, they will not do much if executives can circumvent them in practice.

${ }^{100}$ For a formal model of how hedging can undermine incentives, see Mariano Tommasi \& Federico Weinschelbaum, Principal-Agent Contracts Under the Threat of Insurance, 163 J. INSTITUTIONAL \& THEORETICAL ECON. 379 (2007). 
Thus, as we argued in Pay Without Performance, it is especially important to prohibit hedging and derivative transactions that reduce executives' exposure to fluctuations in the company's stock price. ${ }^{101}$ For these prohibitions to be effective, they must be cast broadly enough to encompass all transactions, no matter how they are labeled, which have the perverse effect of undoing some or all of the intended effects of the company's equity-based arrangements. Firms should accordingly adhere to the following principle:

PRINCIPLE 8: Executives should be prohibited from engaging in any hedging, derivative, or other transaction with an equivalent economic effect that could reduce or limit the extent to which declines in the company's stock price would lower the executive's payoffs or otherwise materially dilute the performance incentives created by the company's equity-based compensation arrangements.

This antihedging principle was incorporated into the policies of the Office of the Special Master for TARP Executive Compensation. Kenneth Feinberg, the Special Master, was charged with supervising the executive pay decisions of several firms that received special assistance from the U.S. government. ${ }^{102}$ The determination decisions issued to the companies subject to the Special Master's supervision require the companies to adopt policies containing antihedging prohibitions in accordance with the above principle. ${ }^{103}$

A small number of companies have announced antihedging policies in their annual proxy statements. Among companies reporting antihedging policies in their 2009 annual proxy statements were Procter \& Gamble, Aetna, and Exxon Mobil. Some of these policies appear comprehensive, banning the use of any derivatives to hedge. For example, Procter \& Gamble "prohibits pledging, collars, short sales,

${ }^{101}$ See BEBCHUK \& FRIED, supra note 1, at 191.

${ }^{102}$ For a description of the Special Master's mandate and work, see Executive Compensation: How Much is Too Much?: Hearing Before the H. Comm. on Oversight and Government Reform, 111th Cong. (Oct. 28, 2009) (statement of Kenneth R. Feinberg, Special Master for TARP Executive Compensation), available at http://oversight.house.gov/images/stories/ TESTIMONY-Feinberg.pdf.

${ }^{103}$ See Press Release, U.S. Dep't of the Treasury, Kenneth R. Feinberg, Special Master for TARP Executive Compensation Written Testimony Before the House Financial Services Committee (Feb. 25, 2010), available at http:/ /www.ustreas.gov/press/releases/ tg565.htm (reporting that one of the principles used to evaluate pay at subject firms was that "employees should be prohibited from engaging in any hedging, derivative or other transactions that undermine the long-term performance incentives created by a company's compensation structures"). 
hedging investments and other derivative transactions involving Company stock." 104 Similarly, Aetna prohibits "all employees (including executives) and Directors from engaging in hedging strategies using puts, calls or other types of derivative securities based upon the value of our Common Stock." 105

In contrast, some of the policies appear to be too narrow to be effective. Exxon Mobil only "prohibits all employees, including executives, from entering into put or call options on Exxon Mobil common stock or futures contracts on oil or gas." ${ }^{, 106}$ Such a policy does not prohibit executives from entering into other derivative transactions not involving actual puts and calls that may have economically equivalent or similar hedging effects. For example, the policy does not prevent Exxon Mobil executives from entering into swap agreements that enable them to offload the risk associated with holding company stock. And Exxon Mobil executives may have a particularly strong incentive to enter into such hedging arrangements because, as we discussed earlier, they are subject to relatively substantial long-term holding requirements. To ensure that executives do not evade these holding requirements, Exxon Mobil should modify its hedging policy to prohibit the use of a broader set of hedging and derivative transactions that could undermine the incentive effects of its long-term holding requirements.

Importantly, to prevent limitations on unwinding from becoming meaningless, firms should curtail executives' ability to engage in certain hedging and derivative transactions as long as the executives are subject to unwinding restrictions. As discussed earlier, it would be desirable to limit the ability of executives to unwind equity-based awards not just during their years of service but also for some time after their departure. In such a case, the limitations on hedging and derivative transactions should also continue after retirement until the executive is no longer subject to unwinding limitations.

If an executive can hedge her unliquidated equity as soon as she retires, she is in the same position as an executive who expects to sell her stock upon retirement. In both cases, the executive's wealth will not depend on how the stock performs during the period between retirement and the cash-out date, but only on the retirement-date price. Thus, when an executive can hedge her position upon retiring, she may have an incentive to depart too early and to adopt an excessively

${ }^{104}$ Procter \& Gamble Co., Definitive Proxy Statement, supra note 36, at 21.

${ }^{105}$ Aetna Inc., Definitive Proxy Statement (Schedule 14A), at 45 (Apr. 22, 2009).

${ }^{106}$ Exxon Mobil Corp., Definitive Proxy Statement, supra note 30, at 26. 
short-term focus in the period leading up to retirement. For postretirement limitations on equity unwinding to function properly, firms must contractually prohibit executives from hedging their equity positions after they retire.

Before closing, we should note the enforcement issues involved in implementing an antihedging prohibition. Such a prohibition in an executive's employment contract is not self-enforcing. While the company may retain control over equity instruments awarded to an executive and thereby easily impose limitations on unwinding, an executive may use her personal account to engage in various hedging and derivative transactions. For executives subject to filing requirements under the securities laws, the company may be able to rely on such filings to determine whether the executive is acting consistently with its antihedging prohibition. However, some top executives may not be subject to such filing requirements, and, moreover, executives are generally no longer subject to such requirements after they leave the firm.

Thus, at least for executives who retire but remain subject to unwinding limitations for a certain period, firms should take steps enforce whatever antihedging prohibitions they have in place. For example, firms could hold the blocked stock of a retired executive in an escrow account and, before releasing the stock on the cash-out date, require the executive to file an affidavit certifying that she has not engaged in any hedging transactions before the cash-out date, either during or before retirement.

\section{CONCLUSION}

In the aftermath of the financial crisis of 2008-2009, there is a growing recognition among firms, investors, and public officials that equity-based compensation awarded to the top executives of public firms should be tied to long-term results and that rewards for short-term gains that may prove illusory can produce substantial distortions. In this Article, we have sought to contribute to the reform of executive pay by providing a framework of analysis for understanding these defects and by putting forward a set of arrangements for remedying them.

We have explained how executives should be incentivized to focus on the long term rather than the short run. Managers should be "blocked" from cashing out their equity for a specified period of time after vesting. Importantly, firms should avoid retirement-based holding requirements that could distort executives' decisions to retire and undermine their incentive to focus on long-term value as they ap- 
proach retirement. Instead, equity-based awards should be subject to grant-based and aggregate limitations on unwinding along the lines we put forward.

We have also explained how firms should structure compensation arrangements to prevent gaming with respect to equity-based awards either at the front end or the back end. Finally, we have stressed the importance of adopting effective prohibitions on hedging and derivative transactions that can undo and undermine the beneficial incentive effects of long-term equity-based plans. We hope that our framework and prescriptions will be useful to firms, compensation experts, investors, policymakers, and regulators in their ongoing efforts to improve executive compensation. 


\section{APPENDIX: PRINCIPLES FOR TYING EQUITY COMPENSATION TO LONG-TERM PERFORMANCE}

PRINCIPLE 1: Executives should not be free to unload restricted stock and options as soon as they vest, except to the extent necessary to cover any taxes arising from vesting.

PRINCIPLE 2: Executives' ability to unwind their equity incentives should not be tied to retirement.

PRINCIPLE 3: After allowing for any cashing out necessary to pay any taxes arising from vesting, equity-based awards should be subject to grant-based limitations on unwinding that allow them to be unwound only gradually, beginning some time after vesting.

PRINCIPLE 4: All equity-based awards should be subject to aggregate limitations on unwinding so that, in each year (including a specified number of years after retirement), an executive may unwind no more than a specified percentage of her equity incentives that is not subject to grant-based limitations on unwinding at the beginning of the year.

PRINCIPLE 5: The timing of equity awards to executives should not be discretionary. Rather, such grants should be made only on prespecified dates.

PRINCIPLE 6: To reduce the potential for gaming, the terms and amount of posthiring equity awards should not be based on the grantdate stock price.

PRINCIPLE 7: To the extent that executives have discretion over the timing of sales of equity incentives not subject to unwinding limitations, executives should announce sales in advance. Alternatively, the unloading of executives' equity incentives should be effected according to a prespecified schedule put in place when the equity is originally granted.

PRINCIPLE 8: Executives should be prohibited from engaging in any hedging, derivative, or other transaction with an equivalent economic effect that could reduce or limit the extent to which declines in the company's stock price would lower the executive's payoffs or oth- 
erwise materially dilute the performance incentives created by the company's equity-based compensation arrangements. 